\title{
Bird species diversity of the Mitidja Plain (Northern Algeria) with EMPHASIS ON THE DYNAMICS OF INVASIVE AND EXPANDING SPECIES
}

\section{Raznovrstnost ptičjih vrst $\mathbf{v}$ nižini Mitidja (severna Alžirija) s poudarkom na dinamiki invazivnih in ekspanzivnih vrst}

\author{
Djamel Bendjoudi ${ }^{1}$, Haroun Chenchoun ${ }^{2}$, Salaheddine Doumandj ${ }^{3}$ \& Jean-François Voisin ${ }^{4}$ \\ ${ }^{1}$ Department of Biology, Agro-veterinary and Biological Faculty, Saad Dahlab University, DZ-09000 Blida, Algeria, \\ e-mail: d_bendjoudi@hotmail.com \\ ${ }^{2}$ Department of Natural and Life Sciences, Faculty of Exact Sciences and Natural and Life Sciences, University of \\ Tebessa, DZ-12002 Tebessa, Algeria, e-mail: chenchouni@gmail.com \\ ${ }^{3}$ Department of Agricultural and Forestry Zoology, National High School of Agronomy - El Harrach, DZ-16200 \\ Algiers, Algeria, e-mail: dmndjislhdn@yahoo.fr \\ ${ }^{4}$ Département Écologie et Gestion de la Biodiversité, UMS 0305 CP 51, 57 rue Cuvier, FR-75005 Paris, France, \\ e-mail: jfvoisin@mnhn.fr
}

This treatise investigates the poorly studied bird fauna of Mitidja Plain (Northern Algeria), with particular notes on the occurrence and expansion of new and alien species. Direct observations, supported by ornithological surveys carried out by Progressive Frequential Sampling (PFS), a version of a point count method, have allowed us to identify 125 bird species. These represent $31 \%$ of all species known from Algeria. The species recorded belong to 14 orders, 39 families and 37 genera. According to their biogeographic origins, 36 are Mediterranean, 32 Palearctic, 24 Holarctic, 17 European and 16 of European-Turkestani origin. The Mitidja Plain holds 60 resident-breeder species ( $48 \%$ of all registered species) and is a transit zone for many migratory species (summer and winter migrants constituting $20 \%$ and $14 \%$ of the total, respectively) and occasional visitors $(\mathrm{RA}=12 \%)$. Among recently expanding species (introduced or local), the Collared Dove Streptopelia decaocto and Wood Pigeon Columba palumbus, sampled by the spot-mapping method, experienced a very rapid population growth. The first observations of the former were made in 1996 in Algiers. Its numbers experienced a steep increase after 2002, starting from 5.75 pairs $/ 10$ ha to reach up to 31.5 pairs $/ 10$ ha in 2006 . The same applies for the Rose-ringed Parakeet Psittacula krameri, surveyed by direct-count at roosting sites. This species has been able to increase and reproduce since its first introduction into the wild in 1996. The increase in study species populations, especially the Rose-ringed Parakeet, may derive from good weather conditions that favoured the species through providing better feeding conditions, thus high reproduction outcomes.

Key words: avian community, bird species diversity, alien species, expanding species, Streptopelia decaocto, Columba palumbus, Psittacula krameri, Mitidja Plain, Algeria

Ključne besede: ptičja združba, raznovrstnost ptičjih vrst, tujerodne vrste, ekspanzivne vrste, Streptopelia decaocto, Columba palumbus, Psittacula krameri, nižina Mitidja, Alžirija 
D. Bendjoudi, H. Chenchouni, S. Doumandji \& J.F. Voisin: Bird species diversity of the Mitidja Plain (Northern Algeria) with emphasis on the dynamics of invasive and expanding species

\section{Introduction}

Worldwide, the monitoring of biodiversity is recognized as an urgent and necessary task accompanying measures to reduce and halt the loss of species, although it raises problems of great complexity (Magurran et al. 2010, Normander et al. 20I2). Owing to their high position in food webs and wide range of ecological requirements, birds are good indicators of the state of biodiversity (BIGGs et al. 2008). Bird monitoring allows to assess the state of ecosystem health and to understand undergoing changes (Lindenmayer \& CunNingham 2OII, MacLeOd et al. 2O I I, ŞeKerCioĞLU 2OI2).

The Mediterranean region is considered one of the global biodiversity hotspots. However, largescale habitat losses and deterioration influence the distribution of bird communities in the region. Many studies dedicated to bird diversity aim to understand factors driving the decline of species diversity and population numbers. Generally, habitat fragmentation (Brotons \& Herrando 200i, Santos et al. 2002) and land abandonment following rural exodus, timber harvesting and overgrazing are the main reasons for biodiversity losses in the Mediterranean basin (Farina 1995, SuÁrez-Seoane et al. 2002, SirAmi et al. 2008).

Biological invasions are one of the greatest threats to ecosystems and one of the main causes for the extinction of many native species. Moreover, interactions between native and alien species do not seem to be simply explained since they are governed by a complex amalgam of parameters (BLACKBURN \& JeSCHKe 2009). Furthermore, evaluating ecological and economic consequences of invasive species has currently become a top priority for biodiversity and ecosystem monitoring (KHUROo et al. 20I I). Invasions have many ecological consequences affecting biodiversity and resulting in harmful interactions with native species or even for biota functioning (MACK et al. 2000, BONTER et al. 20Io): (1) competition that may cause the elimination of native or introduced species (Strubbe \& Matthysen 2007 \& 2009), (2) predation that leads to severe decline or extinction of natives (MACK et al. 2000), (3) rapid change and expansion in species distribution (BLACKBURN et al. 2008, Bonter et al. 20IO, Si Bachir et al. 20II), (4) disease transmission (Mack et al. 2000), and (5) habitat and landscape modifications ( $\mathrm{SoH}$ et al. 2002).

In recent years, the Mitidja Plain in Northern Algeria has experienced significant changes due to urban sprawl. As a result, the surface areas of agricultural lands and forests as well as urban green- spaces have been significantly diminished (HADJIEDJ et al. 2003). Furthermore, recent habitat changes in the Mitidja Plain and the Sahel of Algiers seem to have been caused by climate changes that resulted in a severe drought (1990-2000) followed by irregular annual rainfall during an extended wet period since 2000 (NOM 2008).

This study aims to assess the birds' diversity and their ecological statuses (biogeographical and phenological) in relation to the rapid change of environmental conditions in the Mitidja Plain. Special emphasis is laid on the understanding of the population dynamics of two formerly unknown, but now rapidly expanding breeding birds - the Wood Pigeon Columba palumbus and Collared Dove Streptopelia decaocto - and on the recently introduced Rose-ringed Parakeet Psittacula krameri. Since few studies deal with aspects related to invasions and introductions of non-native bird species in Algeria and northern Africa, the study may be of great interest to conservationists as well as environmental managers.

\section{Material and methods}

\subsection{Study area}

The Mitidja Plain is the largest Algerian sub-coastal plain that stretches almost across $1,500 \mathrm{~km}^{2}$ south of the Sahel of Algiers region and reaches the eastern seaboard at Bordj El Kiffan and Ain Taya. The Plain $\left(36^{\circ} 29^{\prime} \mathrm{N}\right.$ to $36^{\circ} 44^{\prime} \mathrm{N}, 2^{\circ} 25^{\prime} \mathrm{E}$ to $\left.3^{\circ} 17^{\prime} \mathrm{E}\right)$ is the country's most fertile area which, however, has greatly been and still is subjected to agricultural activities. It is actually a depression enclosed by the Tellian Atlas Mountain range in the south and low-altitude subcoastal hills (up to $60 \mathrm{~m}$ a.s.l.) in the north (BENDJOudi 2008). In the east, the Plain borders on a series of hills between Boudouaou and Boumerdes, in the south and southwest on the Blidian Atlas Mountains, and in the west on the mountain ranges of Chenoua and Hadjout (Figure 1).

The climate is typically Mediterranean with dry season extending over four months per year and mean annual temperatures exceeding $15{ }^{\circ} \mathrm{C}$. Precipitation, mostly occurring in winter (ca. 4 months), is characterized by great inter-annual and inter-monthly fluctuations. The coldest month is January (mean temperature 10.1 ${ }^{\circ} \mathrm{C}$.), while the warmest month is August with a mean temperature of $35.6^{\circ} \mathrm{C}$ (NOM 2008).

The Plain is covered by Mediterranean vegetation types. On the banks of wadis that cross the Plain, many forest stands of White Poplar Populus alba, European Ash Fraxinus excelsior, Field Elm Ulmus minor, Cork 


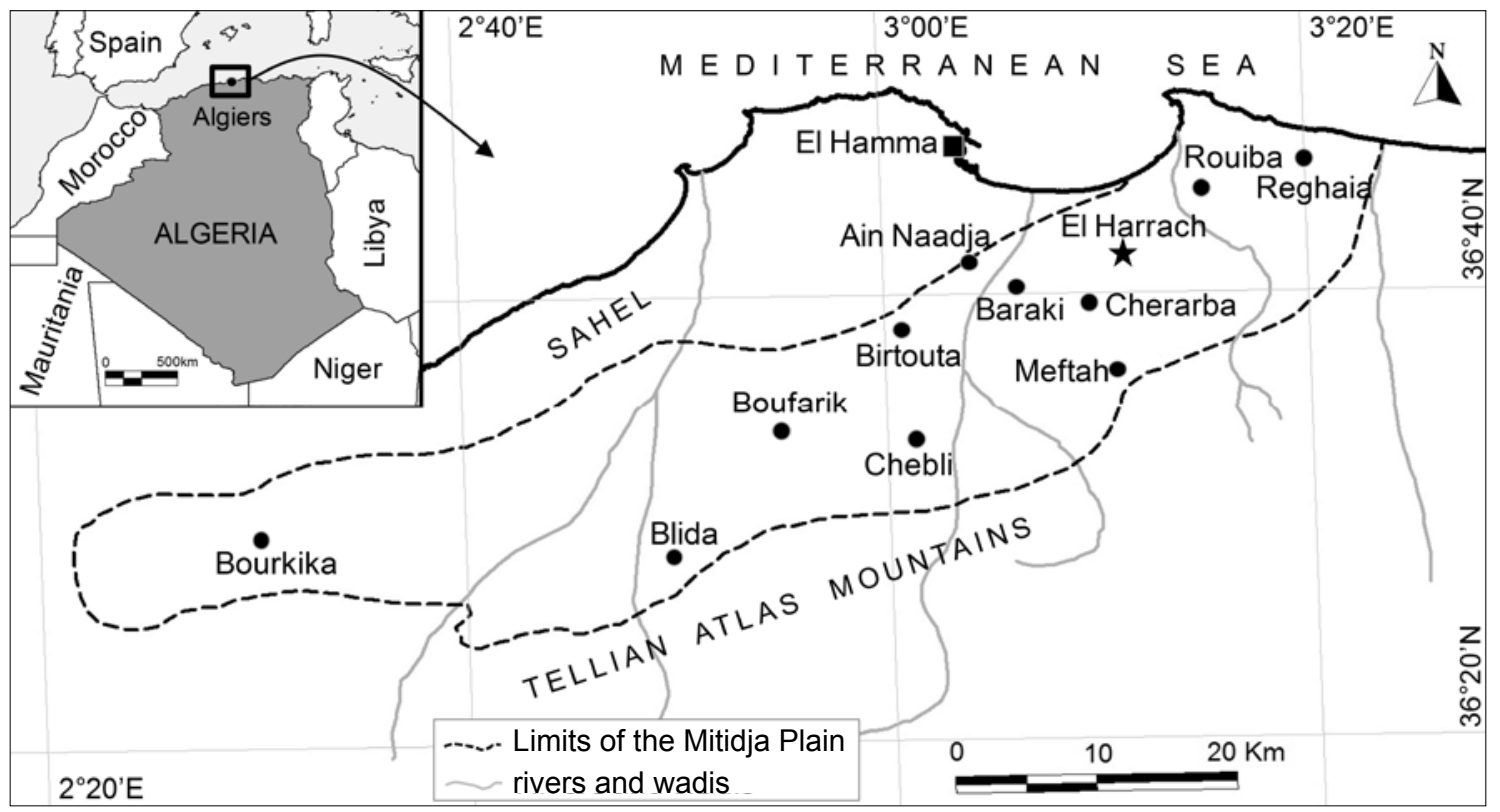

Figure 1: Location of the 12 census points in Mitidja Plain where general bird surveys for collecting data on species diversity $(\bullet)$ and specific census of Columbidae species ( $\star$ ) were carried out; ( $\mathbf{a})$ depicts site where Rose-ringed Parakeet Psittacula krameri was established for the first time

Slika 1: Lokacije 12 popisnih točk v Mitidji, kjer so potekali splošni popisi ptic z namenom zbiranja podatkov o raznovrstnosti ptic v tej nižini $(\bullet)$; lokacija, kjer je bil opravljen poseben popis vrst iz družine Columbidae ( $\star$ ); ( $\mathbf{\square}$ ) ponazarja lokacijo, kjer je bil prvič zabeležen aleksander Psittacula krameri

Oak Quercus suber, River Red Gum Eucalyptus camaldulensis and other tree species can still be seen as remnants of fragmented forests. Large citrus orchards of the Plain are interspersed by plantations of Loquat Eriobotrya japonica and other Rosaceae trees, like apple, pear, peach, apricot, plum and almond, as well as patches of cereal and vegetable crops (BENDJOUdi 2008).

\subsection{Data collection and analysis}

A set of 12 census points was allocated non-randomly, based on accessibility and habitat type. Points were chosen in the manner to get out as many data and information on the Plain's bird populations as possible. Census points were distributed from east to west, as: Reghaia (freshwater coastal marsh), Rouiba (settlements with surrounding orchards of Rosaceae), El Harrach (suburban forest park), Meftah et Cherarba, Baraki, Ain Naadja (agricultural lands), Chebli, Birtouta, Boufarik (citrus orchards), Blida (settlements with surrounding maquis and olive culture) and Bourkika (cereal crops with Fraxinusstands) (Figure 1). Sites located southward the Plain are more natural and influenced by the barrier created by the Tellian Atlas Mountains. However, sites positioned north of Mitidja are characterised by a decreasing gradient of urbanization from east to west. Reghaia site is a coastal wetland represented by marshes that are part of the Oued Reghaia estuary, which drains into the Mediterranean Sea about $30 \mathrm{~km}$ east of Algiers (Figure 1).

For collecting data on species diversity, the Progressive Frequential Sampling (Echantillonnage Fréquentiel Progressif) technique according to Blondel (1975) and Blondel et al. (I98I) was selected. The PFS is a version of point count method that had already been used in several bird studies carried out in Algeria (e.g. Bellatreche I999, Benyacoub \& Chabi 2000). It estimates species richness regardless of species abundances and should be applied under favourable weather conditions between $30 \mathrm{~min}$ before sunrise and $4 \mathrm{~h}$ after it at the most (BlOndel et al. I98I). During each count, all birds heard or seen within a radius of $50 \mathrm{~m}$ around the observer were recorded, and eventually the number of species reported as abundance per 10 ha unit area. Counts were conducted flexibly between February 2004 and December 2006, with an average frequency of three counts per month. 
D. Bendjoudi, H. Chenchouni, S. Doumandji \& J.F. Voisin: Bird species diversity of the Mitidja Plain (Northern Algeria) with emphasis on the dynamics of invasive and expanding species

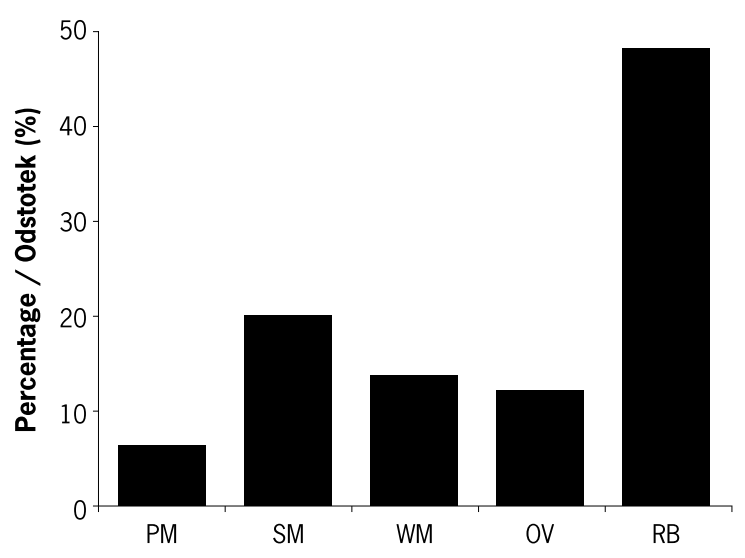

Figure 2: Phenological status of bird species recorded in Mitidja Plain (PM - partial migrant, SM - summer migrant, WM - winter migrant, OV - occasional visitor, RB - resident breeder)

Slika 2: Fenološki status ptičjih vrst, zabeleženih v Mitidji (PM - delna selivka, SM - poletna selivka, WM - zimska selivka, OV - občasna gostja, RB - stalnica-gnezdilka)

Population numbers of expanding species, such as Wood Pigeon and Collared Dove, were investigated by the Territory Mapping Method that is considered the most accurate procedure for measuring bird abundance, specifically in open habitats (BIBBY et al. 1992). The method that plots individuals seen or heard on a gridded map was applied in a single plot of 10 ha in a suburban environment of El Harrach area (Figure 1) during the breeding season (between $15 \mathrm{Feb}$ and 15 Jun) from 1996 to 2006. During each census, the technique was applied during 2.5 hours after sunrise under favourable weather conditions. In total, a set of 7-14 counts was carried out yearly, with a frequency of 2-3 counts per month. Bird population density was given in number of pairs per 10 ha. Of all counts carried out in the 1996-2006 period, only data for the years 1996, 1999, 2002 and 2006 were analysed and included in the present study, as human disturbance was significant in the excluded years and data incomplete.

Population numbers of the Rose-ringed Parakeet were investigated by regular bi-annual counts of roostsites throughout the Mitidja Plain between 1996 and 2006, with the help of 23 volunteer fieldworkers. The bird was searched at sites composed of Eucalyptus groves, old pine stands, trees of mulberry Morus, Pecan Carya illinoinensis or ornamental palms scattered over parks, gardens and surrounding wadis of the Plain. In addition, bird species with large home ranges, such as raptors, waterbirds, swallows, swifts and starlings were recorded occasionally by direct observation all over the Mitidja Plain. Their abundances were estimated semi-quantitatively according to the scale proposed by Benyacoub \& Chabi (2000): (1) abundant species the species is registered almost during every field visit, i.e. present constantly; (2) common species - regular occurrence but not constant; (3) uncommon species finding the species requires some research effort; and (4) rare species - registered only accidentally, i.e. few observations during the entire study period.

All bird species identified in the study area were assigned according to Voous (1960) into biogeographic faunal types. Further, main types were grouped into five main biogeographic categories: Mediterranean, Holarctic, Palearctic, European, and European-Turkestani (BLONDEL et al. I978).

\section{Results}

\subsection{Species diversity}

In total, we recorded 125 bird species in the Mitidja Plain. Of these, 81 species were noted during PFS counts and additional 44 species by occasional observations during ornithological surveys. Of all species, only $14(11 \%)$ were waterbirds. The 125 bird species recorded belong to 14 orders, 39 families and 37 genera. With 16 families and 74 species, the Passeriformes are best represented, followed by Falconiformes ( 2 families, 13 species), Columbiformes (1 family, 7 species) and Charadriiformes (2 families, 5 species) (Table 1). Two species - the Red Kite Milvus milvus and Audouin's Gull Larus audoniniiare cited in the IUCN Red List (IUCN 20I2) as Near Threatened (NT).

\subsection{Biogeographical origins and phenological status}

The identified bird species were distributed across 12 faunal types with $25 \%$ belonging to the Palearctic faunal type. European and European-Turkestani faunal types each held $12-14 \%$ of the species, while the Mediterranean and Holarctic types each included a little more than $10 \%$ of all species. Regarding main biogeographical categories, the Mediterranean category predominated with $29 \%$ over the Palearctic and Holarctic categories with $26 \%$ and $19 \%$ of all bird species, respectively (Table 2). Regarding to breeding status and migration behaviour, 60 species (48\%) were resident breeders, followed by summer migrants $(20 \%)$, winter migrants (14\%) and occasional visitors (12\%) (Figure 2). 
Table 1: List of bird species recorded in Mitidja plain, Algeria between 2004 and 2006 (faunal type: C - Cosmopolitan, E European, ET - European-Turkestani, ETH - Ethiopian, H - Holarctic, IA - Indo-African, M - Mediterranean, OW - Old World, P - Palearctic, PX - Paleoxeric, PXM - Paleo-Xero-Montane, TM - Turkestano-Mediterranean; phenological category: RB resident breeder, WM - winter migrant, SM - summer migrant, PM - partial migrant, OV - occasional visitor; abundance data represents Progressive Frequential Sampling data, given as an average value of species presence per 10 ha and qualitative abundances of bird species with large home ranges: + rare, ++ uncommon, +++ common, ++++ abundant)

Tabela 1: Seznam ptičjih vrst, zabeleženih v nižini Mitidja (Alžirija) med letoma 2004 in 2006 (favnistični tip: C kozmopolitski, E - evropski, ET - evropsko-turkestanski, ETH - etiopski, H - holarktični, IA - indo-afriški, M - mediteranski, OW - stari svet, P - palearktični, PX - paleokserični, PXM - paleo-ksero-montanski, TM - turkestansko-mediteranski; fenološka kategorija: RB - stalnica-gnezdilka, WM - zimska selivka, SM - poletna selivka, PM - delna selivka, OV - občasna gostja; podatki o številčnosti vrst, pridobljeni s progresivnim frekvenčnim vzorčenjem, so podani kot povprečne vrednosti pojavljanja vrst na 10 ha oz. kvalitativno pri ptičjih vrstah z velikim arealom: + redka, ++ občasna, +++ pogosta, ++++ zelo pogosta)

\begin{tabular}{|c|c|c|c|}
\hline Species / Vrsta & $\begin{array}{l}\text { Faunal type/ } \\
\text { Favnistični tip }\end{array}$ & $\begin{array}{l}\text { Phenological category/ } \\
\text { Fenološka kategorija }\end{array}$ & $\begin{array}{l}\text { Abundance/ } \\
\text { Številčnost vrste }\end{array}$ \\
\hline Anas platyrhynchos & $\mathrm{H}$ & WM & ++ \\
\hline Aythya fuligula & $\mathrm{P}$ & WM & ++ \\
\hline Alectoris barbara & M & $\mathrm{RB}$ & 0.67 \\
\hline Coturnix coturnix & OW & $\mathrm{RB}$ & 0.07 \\
\hline Nycticorax nycticorax & $\mathrm{C}$ & PM & + \\
\hline Bubulcus ibis & IA & PM & ++++ \\
\hline Ciconia nigra & $\mathrm{P}$ & $\mathrm{OV}$ & + \\
\hline Ciconia ciconia & $\mathrm{P}$ & PM & +++ \\
\hline Phoenicopterus roseus & OW & WM & ++ \\
\hline Milvus migrans & OW & SM & ++ \\
\hline Milvus milvus & E & WM & + \\
\hline Elanus caeruleus & IA & $\mathrm{RB}$ & +++ \\
\hline Circus aeruginosus & $\mathrm{P}$ & $\mathrm{RB}$ & + \\
\hline Circus cyaneus & $\mathrm{H}$ & WM & ++ \\
\hline Accipiter nisus & $\mathrm{P}$ & $\mathrm{RB}$ & ++ \\
\hline Buteo buteo & $\mathrm{H}$ & $\mathrm{OV}$ & + \\
\hline Buteo rufinus & PX & $\mathrm{RB}$ & ++ \\
\hline Aquila chrysaetos & $\mathrm{H}$ & $\mathrm{RB}$ & + \\
\hline Aquila fasciata & IA & $\mathrm{RB}$ & ++ \\
\hline Falco naumanni & $\mathrm{TM}$ & $\mathrm{OV}$ & + \\
\hline Falco tinnunculus & OW & PM & ++++ \\
\hline Falco peregrinus & $\mathrm{C}$ & $\mathrm{RB}$ & ++ \\
\hline Gallinula chloropus & $\mathrm{C}$ & $\mathrm{RB}$ & $0.3 \mathrm{I}$ \\
\hline Fulica atra & $\mathrm{P}$ & PM & ++ \\
\hline Scolopax rusticola & $\mathrm{P}$ & WM & 0.13 \\
\hline Chroicocephalus ridibundus & $\mathrm{P}$ & WM & ++ \\
\hline Larus audouinii & $\mathrm{M}$ & WM & + \\
\hline Larus fuscus & $\mathrm{P}$ & WM & + \\
\hline Larus michahellis & M & RB & ++++ \\
\hline Pterocles orientalis & PX & $\mathrm{RB}$ & O.IO \\
\hline Columba livia & TM & $\mathrm{RB}$ & I7.I \\
\hline Columba oenas & ET & WM & I. 33 \\
\hline Columba palumbus & ET & $\mathrm{RB}$ & 4.08 \\
\hline Streptopelia decaocto & IA & $\mathrm{RB}$ & 2.14 \\
\hline Streptopelia roseogrisea & IA & $\mathrm{RB}$ & + \\
\hline Streptopelia turtur & ET & SM & $\mathrm{I} 2.0$ \\
\hline Streptopelia senegalensis & Eth & $\mathrm{RB}$ & 0.44 \\
\hline Psittacula krameri & Eth & $\mathrm{RB}$ & ++ \\
\hline Cuculus canorus & $\mathrm{P}$ & SM & O.I4 \\
\hline
\end{tabular}


D. Bendjoudi, H. Chenchouni, S. Doumandji \& J.F. Voisin: Bird species diversity of the Mitidja Plain (Northern Algeria) with emphasis on the dynamics of invasive and expanding species

Continuation of Table 1 / Nadaljevanje tabele 1

\begin{tabular}{|c|c|c|c|}
\hline Species / Vrsta & $\begin{array}{l}\text { Faunal type/ } \\
\text { Favnistični tip }\end{array}$ & $\begin{array}{l}\text { Phenological category/ } \\
\text { Fenološka kategorija }\end{array}$ & $\begin{array}{l}\text { Abundance/ } \\
\text { Številčnost vrste }\end{array}$ \\
\hline Tyto alba & $\mathrm{C}$ & $\mathrm{RB}$ & ++++ \\
\hline Otus scops & OW & SM & ++ \\
\hline Athene noctua & $\mathrm{TM}$ & $\mathrm{RB}$ & +++ \\
\hline Strix aluco & $\mathrm{P}$ & $\mathrm{RB}$ & ++++ \\
\hline Asio otus & $\mathrm{H}$ & $\mathrm{RB}$ & ++ \\
\hline Apus apus & $\mathrm{P}$ & SM & ++ \\
\hline Apus pallidus & M & SM & ++++ \\
\hline Merops apiaster & $\mathrm{TM}$ & SM & 4.17 \\
\hline Coracias garrulus & ET & SM & 0.18 \\
\hline Upupa epops & OW & SM & 0.43 \\
\hline Picus vaillantii & E & $\mathrm{RB}$ & 0.05 \\
\hline Dendrocopos minor & $\mathrm{P}$ & $\mathrm{RB}$ & 0.04 \\
\hline Jynx torquilla mauretanica & $\mathrm{P}$ & $\mathrm{RB}$ & 0.14 \\
\hline Oriolus oriolus & OW & SM & 0.18 \\
\hline Tchagra senegala & Eth & $\mathrm{RB}$ & 0.10 \\
\hline Lanius meridionalis & $\mathrm{H}$ & $\mathrm{RB}$ & 0.85 \\
\hline Lanius senator & M & SM & 0.22 \\
\hline Corvus monedula & $\mathrm{P}$ & $\mathrm{RB}$ & + \\
\hline Corvus corax tingitanus & $\mathrm{H}$ & $\mathrm{RB}$ & +++ \\
\hline Regulus ignicapilla & $\mathrm{H}$ & $\mathrm{RB}$ & 0.08 \\
\hline Cyanistes caeruleus & $\mathrm{E}$ & $\mathrm{RB}$ & I.०O \\
\hline Parus major & $\mathrm{P}$ & $\mathrm{RB}$ & 0.14 \\
\hline Melanocorypha calandra & M & $\mathrm{RB}$ & 0.14 \\
\hline Calandrella brachydactyla & TM & $\mathrm{RB}$ & 0.43 \\
\hline Calandrella rufescens & $\mathrm{TM}$ & $\mathrm{RB}$ & 0.14 \\
\hline Galerida cristata & $\mathrm{P}$ & $\mathrm{RB}$ & 0.54 \\
\hline Galerida theklae & M & $\mathrm{RB}$ & 0.05 \\
\hline Lullula arborea & $\mathrm{E}$ & $\mathrm{RB}$ & 0.21 \\
\hline Alauda arvensis & $\mathrm{P}$ & PM & 1.20 \\
\hline Pycnonotus barbatus & Eth & $\mathrm{RB}$ & I.29 \\
\hline Riparia riparia & $\mathrm{H}$ & OV & + \\
\hline Hirundo rustica & $\mathrm{H}$ & SM & +++ \\
\hline Delichon urbica & $\mathrm{P}$ & SM & +++ \\
\hline Cettia cetti & $\mathrm{TM}$ & $\mathrm{RB}$ & 0.33 \\
\hline Phylloscopus bonelli & $\mathrm{E}$ & SM & O.II \\
\hline Phylloscopus collybita & $\mathrm{P}$ & WM & I.5O \\
\hline Phylloscopus trochilus & $\mathrm{P}$ & $\mathrm{OV}$ & O.II \\
\hline Sylvia atricapilla & E & $\mathrm{RB}$ & I.0O \\
\hline Sylvia borin & $\mathrm{E}$ & $\mathrm{OV}$ & 0.67 \\
\hline Sylvia communis & ET & SM & 0.67 \\
\hline Sylvia conspicillata & M & WM & 0.47 \\
\hline Sylvia cantillans & $\mathrm{M}$ & SM & $0.1 \mathrm{I}$ \\
\hline Sylvia melanocephala & TM & $\mathrm{RB}$ & 0.89 \\
\hline Locustella luscinioides & ET & SM & 0.33 \\
\hline Iduna pallida & M & SM & 0.57 \\
\hline Acrocephalus shoenobaenus & ET & SM & 0.33 \\
\hline Acrocephalus scirpaceus & ET & SM & 0.33 \\
\hline Cisticola juncidis & IA & $\mathrm{RB}$ & 0.56 \\
\hline
\end{tabular}


Continuation of Table 1 / Nadaljevanje tabele 1

\begin{tabular}{|c|c|c|c|}
\hline Species / Vrsta & $\begin{array}{l}\text { Faunal type/ } \\
\text { Favnistični tip }\end{array}$ & $\begin{array}{l}\text { Phenological category/ } \\
\text { Fenološka kategorija }\end{array}$ & $\begin{array}{l}\text { Abundance/ } \\
\text { Številčnost vrste }\end{array}$ \\
\hline Certhia brachydactyla & $\mathrm{E}$ & $\mathrm{RB}$ & 0.14 \\
\hline Troglodytes troglodytes & $\mathrm{H}$ & $\mathrm{RB}$ & 0.50 \\
\hline Sturnus vulgaris & ET & WM & +++ \\
\hline Sturnus unicolor & M & $\mathrm{RB}$ & 0.89 \\
\hline Turdus merula & $\mathrm{P}$ & $\mathrm{RB}$ & 2.50 \\
\hline Turdus philomelos & $\mathrm{E}$ & WM & I. 33 \\
\hline Turdus viscivorus & ET & PM & O.II \\
\hline Muscicapa striata & ET & SM & I.०O \\
\hline Ficedula albicollis & $\mathrm{E}$ & OV & 0.10 \\
\hline Ficedula hypoleuca & $\mathrm{E}$ & OV & 0.09 \\
\hline Erithacus rubecula witherbyi & $\mathrm{E}$ & PM & I.0O \\
\hline Luscinia megarhynchos & E & SM & 0.44 \\
\hline Luscinia svecica & $\mathrm{P}$ & OV & 0.05 \\
\hline Phoenicurus ochruros & PXM & PM & 0.50 \\
\hline Phoenicurus moussieri & M & $\mathrm{RB}$ & 0.14 \\
\hline Phoenicurus phoenicurus & E & OV & 0.10 \\
\hline Monticola solitarius & PXM & $\mathrm{RB}$ & 0.04 \\
\hline Saxicola rubetra & E & $\mathrm{OV}$ & 0.29 \\
\hline Saxicola torquatus & $\mathrm{P}$ & $\mathrm{RB}$ & 0.93 \\
\hline Oenanthe oenanthe & $\mathrm{P}$ & OV & 0.40 \\
\hline Passer domesticus & $\mathrm{P}$ & $\mathrm{RB}$ & 0.10 \\
\hline Passer hispaniolensis & TM & SM & $0 . \mathrm{II}$ \\
\hline P. domesticus $\times$ P. hispaniolensis & 1 & $\mathrm{RB}$ & $6.8 \mathrm{I}$ \\
\hline P. montanus & $\mathrm{P}$ & OV & 0.05 \\
\hline Motacilla flava & $\mathrm{P}$ & SM & 0.33 \\
\hline Motacilla cinerea & $\mathrm{P}$ & WM & 0.29 \\
\hline Motacilla alba & $\mathrm{P}$ & WM & 5.67 \\
\hline Anthus trivialis & ET & $\mathrm{OV}$ & o.II \\
\hline Anthus pratensis & $\mathrm{E}$ & WM & 0.38 \\
\hline Fringilla coelebs africana & $\mathrm{E}$ & $\mathrm{RB}$ & I. 43 \\
\hline Chloris chloris aurantiiventris & ET & $\mathrm{RB}$ & 2.33 \\
\hline Serinus serinus & M & $\mathrm{RB}$ & 5.79 \\
\hline Carduelis carduelis niediecki & ET & $\mathrm{RB}$ & 0.43 \\
\hline Carduelis spinus & $\mathrm{P}$ & $\mathrm{OV}$ & 0.05 \\
\hline Carduelis cannabina mediterranea & ET & $\mathrm{RB}$ & 0.54 \\
\hline Loxia curvirostra poliogyna & ET & $\mathrm{RB}$ & 0.10 \\
\hline Emberiza cirlus & M & $\mathrm{RB}$ & 0.15 \\
\hline Miliaria calandra & ET & $\mathrm{RB}$ & 0.38 \\
\hline
\end{tabular}

\subsection{Population dynamics of the expanding species}

\section{Collared Dove Streptopelia decaocto}

The first individual of this species was noted in 1996 in the suburban habitats of El Harrach near Algiers. In 2002, the Collared Dove breeding density amounted to 5.8 pairs/10 ha (Figure 3). Until 2006, its breeding density increased by almost six-fold to 31.5 pairs/10 ha.

\section{Wood Pigeon Columba palumbus}

The Wood Pigeon nests in both urban trees and in plantations in public parks of El Harrach, and even on roofs of nearby buildings. Its breeding density shows a similar trend as that of the Collared Dove. In 1996, only four pairs were counted by the Territory Mapping Method, while by 2006 its breeding density reached up to 57.3 pairs/10 ha, i.e. a more than 14-times 
D. Bendjoudi, H. Chenchouni, S. Doumandji \& J.F. Voisin: Bird species diversity of the Mitidja Plain (Northern Algeria) with emphasis on the dynamics of invasive and expanding species

Table 2: Biogeographic origins of the bird fauna of Mitidja Plain, Algeria (for explanation of abbreviations see Figure 1)

Tabela 2: Biogeografsko poreklo ptičje favne v nižini Mitidja (za razlago okrajšav glej sliko 1)

\begin{tabular}{|c|c|c|c|c|c|}
\hline $\begin{array}{l}\text { Biogeographic category/ } \\
\text { Biogeografska kategorija } \\
\text { (BLONDEL } \text { et al. I978) }\end{array}$ & $\begin{array}{l}\text { No. of species/ } \\
\text { Število vrst }\end{array}$ & $\begin{array}{c}\text { Percentage/ } \\
\text { Odstotek (\%) }\end{array}$ & $\begin{array}{l}\text { Faunal type/ } \\
\text { Favnistični tip } \\
\text { (Voous I960) }\end{array}$ & $\begin{array}{l}\text { No. of species/ } \\
\text { Število vrst }\end{array}$ & $\begin{array}{l}\text { Percentage/ } \\
\text { Odstotek(\%) }\end{array}$ \\
\hline \multirow[t]{6}{*}{ Mediterranean } & 36 & 28.8 & $\mathrm{M}$ & I3 & IO. 4 \\
\hline & & & $\mathrm{TM}$ & 9 & 7.2 \\
\hline & & & PX & 2 & I. 6 \\
\hline & & & PXM & 2 & I.6 \\
\hline & & & IA & 6 & 4.8 \\
\hline & & & ETH & 4 & 3.2 \\
\hline \multirow[t]{3}{*}{ Holarctic } & 24 & 19.2 & $\mathrm{H}$ & $\mathrm{I} 3$ & IO. 4 \\
\hline & & & OW & 7 & 5.6 \\
\hline & & & $\mathrm{C}$ & 4 & 3.2 \\
\hline Palearctic & 32 & 25.6 & $\mathrm{P}$ & 32 & 25.6 \\
\hline European & I7 & 13.6 & $\mathrm{E}$ & I7 & $\mathrm{I} 3.6$ \\
\hline European-Turkestani & 16 & $\mathrm{I} 2.8$ & ET & I6 & $\mathrm{I} 2.8$ \\
\hline
\end{tabular}

increase since 1996 (Figure 3). A particularly massive population growth took place between 1999 and 2002 when nesting Wood Pigeon's density increased from 9.8 to 48.5 pairs/10 ha. Since then large flocks, sometimes exceeding a hundred individuals, were

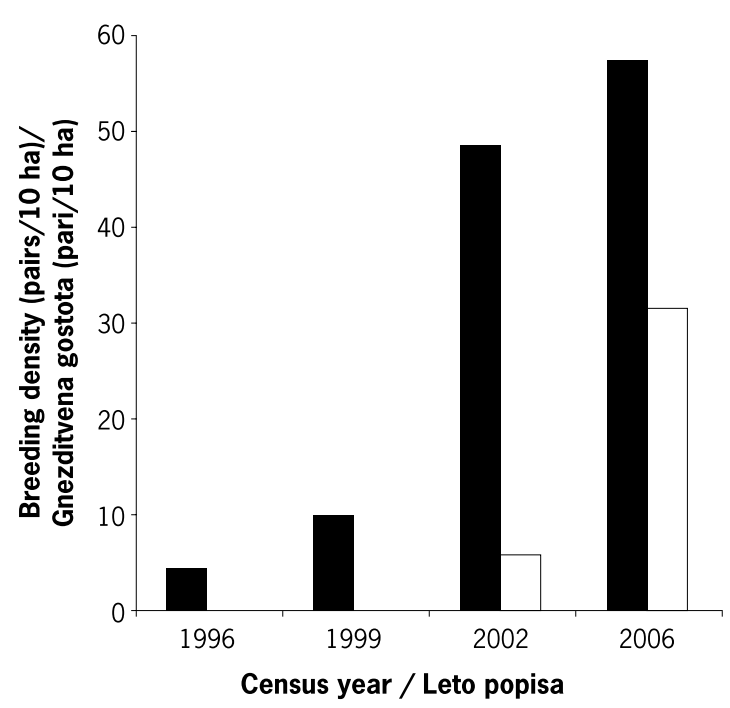

Figure 3: Population size of Wood Pigeon Columba palumbus (black columns) and Collared Dove Streptopelia decaocto (white columns) in the suburban environments of El Harrach (Mitidja Plain, Algeria) in the 1996-2006 period

Slika 3: Velikost populacij grivarja Columba palumbus (črni stolpci) in turške grlice Streptopelia decaocto (beli stolpci) v predmestnih okoljih El Harracha (nižina Mitidja, Alžirija) v obdobju 1996-2006 observed outside El Harrach, even at the limits of the Algiers littoral and Mitidja Plain.

\section{Rose-ringed Parakeet Psittacula krameri}

The Mitidja Plain's population densities increased simultaneously with the species' numbers in the littoral areas of Algiers. In all, we identified two periods of population growth: (1) in 1996-2002, the numbers of visual or auditory contacts with Roseringed Parakeets by regular controls of roost-sites throughout the Plain increased nearly 12-times from four to 46 individuals at all roost sites together, (2) the period 2002-2004 was marked by a rapid increase of Rose-ringed Parakeets in the Plain, where the total number of parakeets on all roost-sites jumped to 342 individuals in 2004 , i.e. $80.1 \%$ of the total numbers recorded in 2006, which was 422 individuals (Figure 4 ). The number of roost-sites reported between 2004 and 2006 was seven and 11 sites, respectively. In 2004, about 80 parakeets were counted in a roost-site located around Reghaia. However, in 2006 over 108 Rose-ringed Parakeets were counted in Haouch El Makhfi (Meftah).

\section{Discussion}

\subsection{Species numbers and species diversity}

With 125 bird species recorded during our study, the avifauna of the Mitidja Plain is rich, despite various disturbances occurring in the region (urbanization, intensive farming practices, poaching, etc.). In 


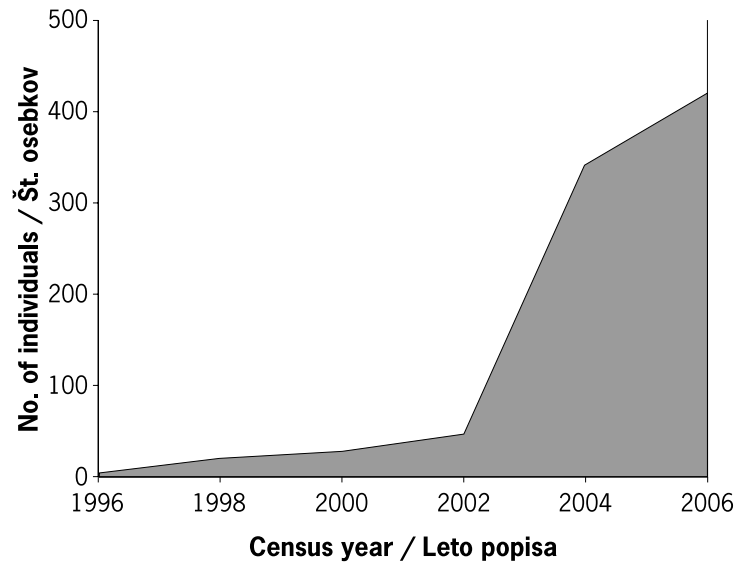

Figure 4: Population growth of Rose-ringed Parakeet Psittacula krameri in Mitidja Plain and surrounding areas of Algiers, based on the counts of individuals on roost-sites

Slika 4: Populacijska rast aleksandra Psittacula krameri v Mitidji in sosednjih območjih Alžira, ugotovljena s štetjem osebkov na prenočiščih

comparison to the Algerian bird list of 406 species (ISENMANN \& MOALI 2000), our inventory embraces $31 \%$ of the country's bird fauna.

According to the classifications by Voous (I960) and Blondel et al. (1978), the majority of Mitidja's birds belong to the Palearctic fauna (32 species, 26\%), followed by species of European (17 species, 14\%) and European-Turkestani (16 species, 13\%) origins. Many studies in Algeria and in other North African countries have shown high proportions of bird species linked to the Palearctic biogeographic region (Fellous i990, Thevenot i99I, IsenManN \& Moali 2000, Isenmann et al. 2005, Bendjoudi 2008). In the Mitidja Plain, most species belong to the Mediterranean broad biogeographical category $(29 \%)$. This agrees with the former Algerian studies by LEDANT et al. (198I) for the nationwide avifauna (41\%), Bellatreche (1994) for the Kabylie-Babors area (38\%) and Bellatreche (1999) for the Babor Mountain (35\%), all of which stated that the Algerian avifauna has clear Mediterranean affinities. Only Fellous (I990) found that in the bird fauna of the National Park of Theniet-El-Had in Tellian Atlas Mountains, species of Boreal origins predominate (65\%).

The occurrence of some species in the Mitidja Plain depends on the presence of intensively cultivated fields of vegetables and cereals. This applies particularly for some granivorous birds, whose numbers are increasing, like Turtle Streptopelia turtur, Laughing S. senegalensis and Collared Doves, Rock Dove Columba livia and Wood Pigeon. Obviously, the same concerns some Fringillidae and Passeridae, like Greenfinch Chloris chloris, Serin Serinus serinus and hybrid sparrows Passer sp. (Bendjoudi 2008). It is noteworthy that the hybrid sparrows and doves are experiencing wide outbreak in several Algerian regions even in hyper-arid environments (Guezoul et al. 2013). Additionally, certain frugivorous species, in particular the Common Bulbul Pycnonotus barbatus and Blackbird Turdus merula, were found in high densities. In contrast, some species that are more susceptible to human impacts breed in smaller numbers; e.g. Nightingale Luscinia megarhynchos, Woodcock Scolopax rusticola, Wryneck Jynx torquilla and Lesser Spotted Woodpecker Dendrocops minor. In general, the dissimilarity between species densities may reflect the decrease of natural and agricultural lands, interspersed by trees, bushes and shrubs, following the expansion of urban and industrial areas in recent years.

Like in Morocco, the majority of breeding bird species inhabiting the Plain's cork oak forests are resident breeders (Thevenot i99I). In the KabylieBabors (Algeria), the proportion of sedentary species is higher than that of summer migrants (BELLATRECHE 1994). With $69 \%$ out of 214 breeding species, the proportion of resident breeders also dominates in Algeria in general (Isenmann \& Moali 2000). Our study further reveals that some partial migrants like the Yellow-legged Gull Larus michahellis and Cattle Egret Bubulcus ibis tend to be resident in the region for a longer period of the year over the last three decades. For example, the Cattle Egret was observed during almost the whole year of 2006, except in July. Its mean numbers were more important in March, August and December (Bendjoudi 2008).

Similarly to the Kabylie-Babors region with $20 \%$ (Bellatreche I994), the proportion of summer migrants is rather low in the Mitidja Plain, while in other areas of North Africa summer migrants surpass the numbers of other groups: e.g. in Moutas Cynegetic Reserve near Tlemcen in Western Algeria summer migrants dominate with 39\% of all species (Mostefal 1997), with $31 \%$ in Tamentit Oasis in the central Sahara (Cherifr 2003), and with $28 \%$ in the Iforas-Adrar Massif in northern Mali (CLOUET \& GOAR 2003). The small number of summer migrants in the Mitidja Plain may be due to lack of suitable nest-sites. In addition, the impact of human pressure, urban sprawl and intensive exploitation of farmland is probably among the causes for small number of summer migrant birds, which use Mitidja as a stopover before/after crossing the Sahara Desert. Resident 
D. Bendjoudi, H. Chenchouni, S. Doumandji \& J.F. Voisin: Bird species diversity of the Mitidja Plain (Northern Algeria) with emphasis on the dynamics of invasive and expanding species

breeders are more abundant as they well adapt to the favourable climatic conditions of the Plain; therein these birds find sufficient food throughout the year (Doumandji \& Doumandji-Mitiche i992, BendjOudi 2008).

\subsection{Recent trends of expanding species}

\section{Collared Dove and Wood Pigeon}

The rapid increase of both Columbidae species in our study area coincides with similar trends of these species in several other regions worldwide (ERAud et al. 2007, Barnard \& Thuiller 2008, Bonter et al. 2010, FuJISAKI et al. 2010).

The first observation of Collared Dove in Annaba in Algeria goes back to 1994 (Benyacoub 1998), while in Tunisia the species is present for a longer period (Isenmann et al. 2005). In Morocco, the species is a well-established breeding bird (BERGIER et al. 1999). Like in other parts of North Africa, population numbers have grown considerably in the Mitidja Plain. Benyacoub (I998), who investigated the population dynamics of Collared Dove in the northern outskirts of Annaba city (eastern Algeria), highlighted a rapid expansion of the population newly established; nevertheless, he reported that this population growth could not be attributed to the local reproduction but to the migration flow. The species increased in a number of European countries. The increase was most notable along the Mediterranean and in Western Europe (Birdlife International 2004).

Wood Pigeons occur everywhere in our study area. However, nearly two decades ago the species was absent in some habitats, while mainly frequenting parks and large gardens. A sudden and large increase of the breeding densities was noted between 2001 and 2002. The population growth is further reflected by large groups of sometimes more than a hundred Wood Pigeons, which could be seen in transition zone between the Algiers littoral and Mitidja Plain. In Egypt, the species still appears to be very rare. Only a single individual was observed in the 1990s (Miles I998), similarly to a suburban park near El Harrach in the eastern littoral plain of Algiers. In different forests of the Kabylie-Babors area in North Algeria, breeding densities were relatively low, with numbers ranging from 0.02-0.35 pairs/10 ha (Bellatreche I994). In France, the population increase may be linked to the establishment of resident winter populations - a phenomenon attributed by Julliard \& Jiguet (2005) to the increase of cereal crops. However, in SE Austria the same trend was observed when cereal crops have sharply declined; and the establishment of winter populations coincide with milder temperatures and less snow in winter (P. SACKL pers. comm.). The population growth of Wood Pigeon in the study area is probably due to the reduced hunting pressure for more than a decade in Algeria. Also, even if poaching continues, it remains insignificant. The growth may also be related to a change in the species diet. These birds used to feed mainly in the forests of the Atlas Mountains, where all kinds of food were abundant, but since 1990 the violent forest fires occurring each year in the region (SAHAR-Meddour et al. 2008) have significantly reduced these food resources. Deprived of a large part of their usual food, the pigeons thus had to concentrate on food resources of adjacent farmlands in the Mitidja Plain.

According to personal observations of the species in different seasons and in several habitats (parks, gardens, suburban environments etc.), where it is present together with Turtle, Laughing and Rock Doves, the Collared Dove appears not to face any competition by other Columbidae, neither in winter (by Laughing Dove) nor in summer (by Turtle Dove). This is due to the fact that this highly synanthropic species does not utilise the same feeding habitats as the other two doves, which means that it resorts to eating somewhat different food (Benyacoub i 998, Bendjoudi 2008). Apparently, the invasion and range expansion of this species is closely related to human activities. Among factors influencing its colonization are those related to the size, fragmentation and connectivity between patches of urban areas, as well agricultural practices and weather conditions (ERAUd et al. 2007, FuJISAKI et al. 2010), which applies for many alien species as well (BLACKBURn et al. 2008).

\section{Rose-ringed Parakeet}

The occurrence of Rose-ringed Parakeet in the study area is due to 6-8 individuals that escaped from aviaries in the Garden of Hamma (Algiers) between 1988-1990. Free-ranging birds were maintained in Hamma Garden and its immediate vicinity, where the first signs of reproduction were noted a few years following their escape. From 1988-1990, the established pairs remained sedentary in Hamma Garden and its immediate neighbourhoods. After 1990, their offspring moved away from the centre to the periphery of Algiers, while increased population size was noted in various localities within the Algiers region, where the species had already established itself (Metriter pers. comm., Moulai i997, Bendjoudi et al. 2005A, Fellous et al. 2005, Bendjoudi et al. 2006). 
The Rose-ringed Parakeet started to expand its range in Algeria when offspring of the already established breeding pairs moved out of Hamma Garden into other localities of the Mitidja Plain (Bendjoudi et al. $2005 \mathrm{~B})$. In Morocco, the first record of the species was noted in 1999 near Nador, located $60 \mathrm{~km}$ east from the border with Algeria (BERGIER et al. 2000).

From 1996-2002, the population numbers of Roseringed Parakeets in Mitidja Plain amounted to $11 \%$, compared to a total population of 422 individuals in 2006. In Britain, the population was estimated at 1,508 individuals in October 1996, 1,880 individuals in August 1997 (20\% increase) and 2,060 individuals in September 1998, i.e. a further $27 \%$ increase (Pithon \& Dytham 2002). The authors conclude the British population is relatively small and its expansion slow. Despite the low geographical expansion of the Rose-ringed Parakeet in Paris (France) compared to other European cities (Clergeau \& Vergnes 2009), the establishment of the species and its current status suggest an expansion and a rapid increase in numbers (Clergeau et al. 2009).

Various reasons are under consideration to explain the slow expansion of Rose-ringed Parakeets in unfavourable habitats located outside their natural range. Climatic hazards such as frost and fog are among the main factors that can induce high mortality (TAMARA \& ARNHEM I996). However, this is not the case when considering the milder temperatures throughout the year in our study area. Thus, we suppose that other mortality factors such as (1) high predation rates by raptors, especially owls, (2) trapping of adults during the breeding season and (3) poaching play a key role in regulating the population size of the Rose-ringed Parakeet around Algiers.

The increase of Rose-ringed Parakeets in the Mitidja Plain may derive from favourable climatic conditions due to a significant amount of rainfall in 2003. The 2002 was a year of severe drought, probably the longest for decades in Algeria that lasted eight months from February to October. In contrast, 2003 was exceptionally wet, totalling $736 \mathrm{~mm}$ of precipitation spread over a wet period of almost seven months from mid-October to early May the following year. These weather conditions favoured the species through providing better feeding conditions, thus its high reproduction success and low mortality. In fact, the distribution of Algerian Rose-ringed Parakeet is governed mainly by the sub-humid climate with warm to temperate winter. Moreover, these climatic conditions support the development of many fruiting plant species in the Plain. Many tropical fruiting trees, which were introduced in the Garden of Hamma during the colonial period (1860-1962), were eventually dispersed to home gardens throughout the Algiers Sahel and the northern edge of the Mitidja Plain, which has diversified food resources for many birds, including alien species (Bendjoudi et al. 2005B).

Considering the faunal and phenological status, the bird community of Mitidja Plain is fairly similar to those in other regions in either Algeria or North Africa. However, during the last decades a rapid population increase has been observed in species established recently in the area. The review of the current distribution and further expansion of expanding bird species, including Collared Dove, Wood Pigeon and Rose-ringed Parakeet, in the Mitidja Plain within a broader geographic context is crucial for understanding environmental factors driving range expansion and population dynamics, which will help to mitigate potential risks they may pose to the environment.

Acknowledgements: We thank all volunteer observers (birders) who helped with fieldwork. We particularly acknowledge the assistance of Ahmed Arrougani, Ahmed Gaid, Kamel Hamadi, Ilies Kouider, Omar Guezoul, Moussa Metriter, Salim Laïb, Kouider Nadjem, Salah Telailia, Louisa Remini, Samira Setbel, Samia Ouarab, Samira Doumandji and Faiza Marniche. We are grateful to Prof. Philippe Clergeau (MNHN Paris, France) for his comments on an earlier version of the manuscript. This study was carried outs within the framework of Franco-Algerian cooperation program "Tassili" No. 08MDU726. Finally, our thanks go also to the two referees and the editor for their relevant comments, which greatly improved the manuscript.

\section{Povzetek}

Pričujoči prispevek obravnava doslej slabo preučevano ptičjo favno nižine Mitidja $\mathrm{v}$ severni Alžiriji, s posebnimi poudarki o pojavljanju in širitvi novih in tujerodnih vrst. Neposredna opažanja s podporo progresivnega frekvenčnega vzorčenja (različica metode točkovnega štetja) so raziskovalcem omogočila določiti 125 vrst ptic, kar pomeni $31 \%$ vseh vrst, pojavljajočih se v Alžiriji. Zabeležene vrste pripadajo 14 redovom, 39 družinam in 37 rodovom ptic. Glede na biogeografski izvor je 36 vrst sredozemskih, 32 palearktičnih, 24 holarktičnih, 17 evropskih in 16 evropsko-turkestanskih. Nižino naseljuje 60 gnezdilkstalnic ( $48 \%$ vseh zabeleženih vrst), sicer pa je to nižavje tudi selitveno območje za mnoge selivke (poletne in zimske, ki sestavljajo $20 \%$ oz. $14 \%$ vseh vrst) in občasne gostje (12\%). Med novejšimi 
D. Bendjoudi, H. Chenchouni, S. Doumandji \& J.F. Voisin: Bird species diversity of the Mitidja Plain (Northern Algeria) with emphasis on the dynamics of invasive and expanding species

ekspanzivnimi vrstami (vnešenimi ali avtohtonimi) je bilo $s$ točkovnim kartiranjem opaziti zelo naglo rast populacij turške grlice Streptopelia decaocto in grivarja Columba palumbus. Prva opažanja turške grlice so bila zabeležena leta 1996 v Alžiru, njeno število pa je začelo naglo naraščati po letu 2002 s 5,75 para/10 ha, višek pa doseglo leta 2006 z 31,5 para/10 ha. Enako velja za aleksandra Psittacula krameri, ki je bil preštet neposredno na prenočiščih; širiti se je začel po letu 1996, ko je bil naseljen. Rast populacij preučevanih vrst, posebno aleksandra, gre verjetno pripisati ugodnim vremenskim razmeram, ki vrstam omogočajo boljšo prehrano in zatorej tudi uspešno razmnoževanje.

\section{References}

Barnard, P. \& Thuiller, W. (2008): Introduction. Global change and biodiversity: future challenges. - Biological Letters 4 (5): 553-555.

Bellatreche, M. (I994): [Ecology and biogeography of forest birds of Babors and Kabylie (Algeria).] PhD thesis. - University of Burgundy, Dijon. (in French)

Bellatreche, M. (I999): Biological diversity and conservation: the case of the forest nest-building avifauna of the Kabylie des Babors in Algeria. - Wildlife and Nature 15: 37-48.

Bendjoudi, D. (2008): [Study of the avifauna of Mitidja.] PhD thesis. - National Agronomical Institute, El Harrach, Algiers. (in French)

Bendjoudi, D., Voisin, J.F., Baziz, B. \& Doumandji, S. (2005A): Premières données sur la présence et l'extension de la Perruche à collier Psittacula krameri (Scopoli) (Aves, Psittacidae) en Algérie. - Ornithologia Algirica 5 (1): 26-35.

Bendjoudi, D., Voisin, J.F., Doumandji, S. \& Baziz, B. (2005B): Installation de la Perruche à collier Psittacula krameri (Aves, Psittacidae) dans l'Algérois et premières données sur son écologie trophique dans cette région. Alauda 73 (3): 329-334.

Bendjoudi, D., Doumandji, S. \& Voisin, J.F. (2006): La Perruche à collier Psittacula krameri, nouvelle espèce faisant partie de l'avifaune algérienne. $10^{\text {th }}$ National Days of Ornithology, 6 March 2006. - National Agronomical Institute, El Harrach, Algiers.

Benyacoub, S. \& Chabi, Y. (2000): Diagnose écologique de l'avifaune du parc national d'El Kala. - Synthèse 7: 1-98.

Benyacoub, S. (I 998): La Tourterelle turque Streptopelia decaocto en Algérie. - Alauda 66 (3): 251-253.

Bergier, P., Franchimont, J. \& Thévenot, M. (i 999): Implantation et expansion géographique de deux espèces de Columbidés au Maroc: La Tourterelle turque Streptopelia decaocto et la Tourterelle maillée Streptopelia senegalensis. - Alauda 67 (1): 23-36.

Bergier, P., Franchimont, J., Thevenot, M. \& La Commission D'homologation marocaine (2000): Les oiseaux rares au Maroc. Rapport de la Commission d'Homologation Marocaine. - Porphyrio 12 (6): 57-69.
Bibby, C.J., Burgess, N.D. \& Hill, D.A. (I992): Bird census techniques. - Academic Press, London.

Biggs, R., Simons, H., Bakkenes, M., Scholes, R.J., Eickhout, B., Vuuren, D.V. \& Alkemade, R. (2008): Scenarios of biodiversity loss in southern Africa in the 21st century. - Global Environmental Change 18 (2): 296-309.

Birdlife International (2004): Birds in Europe: population estimates, trends and conservation status. BirdLife Conservation Series No. 12. - BirdLife International, Cambridge.

BlaCkburn, T.M. \& JesChKe, J.M. (2009): Invasion success and threat status: two sides of a different coin? Ecography 32 (1): 83-88.

Blackburn, T.M., Cassey, P. \& Lockwood, J.L. (2008): The island biogeography of exotic bird species. - Global Ecology and Biogeography 17 (2): 246-251.

Blondel, J. (I975): L'analyse des peuplements d'oiseaux éléments d'un diagnostic Ecologique: La méthode des échantillonnages fréquentiels progressifs (E.F.P.). - Revue d'Ecologie (La Terre et la Vie) 29 (4): 533-589.

Blondel, J., David, P., Lepart, J. \& Romane, F. (I978): L'avifaune du Mont-Ventoux, essai de synthèse biogéographique et écologique. - Revue d'Ecologie (La Terre et la Vie) 32, Suppl.: 111-145.

Blondel, J., Ferry, C. \& Frochot, B. (I98 I): Point counts with unlimited distance. - Studies in Avian Biology 6: 414-420.

Bonter, D.N., Zuckerberg, B. \& Dickinson, J.L. (20 io): Invasive birds in a novel landscape: habitat associations and effects on established species. - Ecography 33 (3): 494-502.

Brotons, L. \& Herrando, S. (200I): Factors affecting bird communities in fragments of secondary pine forests in the north-western Mediterranean basin. - Acta Oecologica 22 (1): $21-31$.

Cherifi, T. (2003): [Bird diversity of Tamentit oasis (central Sahara).] Oral presentation at $7^{\text {th }}$ ornithological conference, 10 March 2003. - National Agronomical Institute, El Harrach, Algiers. (in French)

Clergeau, P. \& Vergnes, A. (2009): La Perruche à collier Psittacula krameri introduite en Île-de-France: Dispersion et approche des impacts. - Report MNHN-ODBU, Paris.

Clergeau, P., Vergnes, A. \& Delanque, R. (2009): La Perruche à collier Psittacula krameri introduite en Île-deFrance: Distribution et régime alimentaire. - Alauda 77 (2): 121-132.

Clouet, M. \& Goar, J.L. (2003): L'avifaune de l'Adrar Tirharhar / Adrar des Iforas (Mali). - Alauda 71 (4): 469-474.

Doumandji, S. \& Doumandji-Mitiche, B. (i 992): Relations trophiques insects/oiseaux dans un parc du littoral algérois (Algérie). - Alauda 40 (4): 274-275.

Eraud, C., Boutin, J.-M., Roux, D. \& Faivre, B. (2007): Spatial dynamics of an invasive bird species assessed using robust design occupancy analysis: the case of the Eurasian collared dove (Streptopelia decaocto) in France. Journal of Biogeography 34 (6): 1077-1086.

FARINA, A. (1995): Distribution and dynamics of birds in a rural sub-Mediterranean landscape. - Landscape and 
Urban Planning 31 (1/2/3): 269-280.

Fellous, A. (1990): [Contribution to the study of the avifauna of the national park of Theniet-El-Had (W. Tissemsilt).] Engineer dissertation. - National Agronomical Institute, El Harrach, Algiers. (in French)

Fellous, A., Moulai, R. \& JасOB, J.P. (2005): Introduction et nidification de la Perruche à collier (Psittacula krameri) en Algérie. - Aves 42 (3): 272-277.

Fujisaki, I., Pearlstine, E.V. \& Mazzotti, F.J. (20io): The rapid spread of invasive Eurasian Collared Doves Streptopelia decaocto in the continental USA follows human-altered habitats. - Ibis 152 (3): 622-632.

Guezoul, O., Chenchouni, H., Sekour, M., Ababsa, L., Souttou, K. \& Doumandji, S. (2013): An Avifaunal Survey of Mesic Manmade Ecosystems "Oases" in Algerian Hot-Hyperarid Lands. - Saudi Journal of Biological Sciences 20 (1): 37-43.

Hadjiedj, A., Chaline, C., Dubois-Maury, J. \& Djedounini, S. (2003): Alger, les nouveaux défis de l'urbanisation. - Ed. University of Sciences and Technology Houari Boumediene, Algiers.

Isenmann, P. \& Moali, A. (2000): Oiseaux d'Algérie - Birds of Algeria. - French Society of Ornithological Studies, MNHN, Paris.

Isenmann, P., Gaultier, Th., El Hilli, A., Azafzaf, H., Dlensi, H. \& Smart, M. (2005): Oiseaux de Tunisie - Birds of Tunisia. - French Society of Ornithological Studies, MNHN, Paris.

IUCN (2OI 2): The IUCN Red List of Threatened Species. Version 2012.1 - [www.iucnredlist.org], 4/10/2012.

Julliard, R. \& Jiguet, F. (2005): Statut de conservation en 2003 des oiseaux communs nicheurs en France selon 15 ans de programme Stoc. - Alauda 73 (4): 345-356.

Khuroo, A.A., Reshi, Z.A., Rashid, I. \& Dar, G.H. (20II): Towards an integrated research framework and policy agenda on biological invasions in the developing world: A case-study of India. - Environmental Research 111 (7): 999-1006.

Ledant, J.-P., Jасов, J.-P., JaCobs, P., Malher, F., Ochando, B. \& Roche, J. (I98I): Mise à jour de l'avifaune algérienne. - Le Gerfaut-De-Giervalk 71: 295-398.

Lindenmayer, D.B. \& Cunningham, R.B. (201 I): Longitudinal patterns in bird reporting rates in a threatened ecosystem: Is change regionally consistent? - Biological Conservation 144 (1): 430-440.

Mack, R.N., Simberloff, D., Lonsdale, W.M., Evans, H., Clout, M. \& BAzzaz, F.A. (2000): Biotic invasions: causes, epidemiology, global consequences, and control. - Ecological Applications 10 (3): 689-710.

Macleod, R., Herzog, S.K., Maccormick, A., Ewing, S.R., Bryce, R. \& Evans, K. (20I I): Rapid monitoring of species abundance for biodiversity conservation: Consistency and reliability of the MacKinnon lists technique. - Biological Conservation 144 (5): 13741381.

Magurran, A.E., Baillie, S.R., Buckland, S.T., Dick, J.M., Elston, D.A., Scott, E.M., Smith, R.I., SOMERFIEld P.J. \& WATT, A.D. (20I0): Long-term datasets in biodiversity research and monitoring: assessing change in ecological communities through time. - Trends in Ecology and Evolution 25 (10): $574-$ 582.

Meddour-Sahar, O., Meddour, R. \& Derridj, A. (2008): Analyse des feux de forêts en Algérie sur le temps long (1876-2007). - Les Notes d'analyse du CIHEAM 39: 11.

Miles, J. (I998): Pharaoh's Birds. A guide to ancient and present day birds in Egypt. - The American University in Cairo Press, Cairo.

Mostefai, N. (I997): [Test of ecological analysis of the avifauna of Moutas hunting reserve (Tlemcen, Algeria).] Oral presentation at $2^{\text {nd }}$ ornithological conference, 15 17 March 1997. - National Agronomical Institute, El Harrach, Algiers. (in French)

MoulaI, R. (I 997): [Composition, structure and dynamics of bird populations of Hamma Garden (Algiers) and essay for estimating populations of Commun starling Sturnus vulgaris (Linnaeus, 1758) (Aves, Sturnidae) in their dormitories.] MSc thesis. - National Agronomical Institute, El Harrach, Algiers. (in French)

NOM (2008): [Meteorological records of the National Office of Meteorology.] - Ed. National Office of Meteorology (NOM), Dar El-Beida, Algiers. (in French)

Normander, B., Levin, G., Auvinen, A.-P., Bratli, H., Stabbetorp, O., Нedblom, M., Glimskär, A. \& Gudmundsson, A.G. (2012): Indicator framework for measuring quantity and quality of biodiversity - Exemplified in the Nordic countries. - Ecological Indicators 13 (1): 104-116.

Pithon, J.A. \& Dytham, C. (I999): Census of the British population of Ring-necked Parakeet Psittacula krameri by simultaneous roost counts. - Bird Study 46 (1): 112115.

Pithon, J.A. \& Dytham, C. (2002): Distribution and population development of introduced Ring-necked Parakeets Psittacula krameri in Britain between 1983 and 1998. - Bird Study 49 (2): 110-117.

Santos, T., Tellerí́a, J.L. \& Carbonell, R. (2002): Bird conservation in fragmented Mediterranean forests of Spain: effects of geographical location, habitat and landscape degradation. - Biological Conservation 105 (1): 113-125.

ŞEKercioĞLU, Ç.H. (20 I 2): Promoting community-based bird monitoring in the tropics: Conservation, research, environmental education, capacity-building, and local incomes. - Biological Conservation 151 (1): 69-73.

Selmi, S. (2000): Données nouvelles sur les avifaunes des oasis du Sud Tunisien. - Alauda 68 (3): 201-212.

Si Bachir, A., Ferrah, F, Barbraud, C., Céréghino, R. \& Santoul, F. (20I I): The recent expansion of an avian invasive species (the Cattle Egret Ardea ibis) in Algeria. Journal of Arid Environments 75 (11):1232-1236.

Sirami, C., Brotons, L., Burfield, I., Fonderflick, J. \& Martin, J.-L. (2008): Is land abandonment having an impact on biodiversity? A meta-analytical approach to bird distribution changes in the north-western Mediterranean. - Biological Conservation 141 (2): 450 459.

SoH, M.C.K., Sodhi, N.S.S., SeOH, R.K.H. \& Brook, B.W. (2002): Nest site selection of the house crow (Corvus splendens), an urban invasive bird species in Singapore 
D. Bendjoudi, H. Chenchouni, S. Doumandji \& J.F. Voisin: Bird species diversity of the Mitidja Plain (Northern Algeria) with emphasis on the dynamics of invasive and expanding species

and implications for its management. - Landscape and Urban Planning 59 (4): 217-226.

Strubbe, D. \& Matthysen, E. (2007): Invasive Ringnecked Parakeets Psittacula krameri in Belgium: habitat selection and impact on native birds. - Ecography 30 (4): $578-588$.

Strubbe, D. \& Matthysen, E. (2009): Experimental evidence for nest-site competition between invasive ring-necked parakeets (Psittacula krameri) and native nuthatches (Sitta europaea). - Biological Conservation 142 (8): 1588-1594.

Suárez-Seoanea, S., Osborne, P.E. \& Baudry, J. (2002): Responses of birds of different biogeographic origins and habitat requirements to agricultural land abandonment in northern Spain. - Biological Conservation 105 (3): 333-344.

Tamara, K. \& Arnhem, R. (I996): Perruches à collier (Psittacula krameri) victimes des conditions climatiques en région bruxelloise. - Aves 33: 128-129.

Thevenot, M. (I99I): Les oiseaux des forêts de chêne-liège du Maroc. pp. 197-233 In: Villemant, C. \& Fraval, A. (eds.): La faune du Chêne liège. - Actes Editions Inst. Agro. Vet. Hassan II, Rabat.

Voous, K.H. (I960): Atlas of European Birds. - Nelson, Amsterdam, London.

Arrived / Prispelo: 21. 5. 2012

Accepted / Sprejeto: 24. 2. 2014 